Research Paper

\title{
Serum Ferritin as a Prognostic Biomarker for Survival in Relapsed or Refractory Metastatic Colorectal Cancer
}

\author{
Sookyung Lee ${ }^{1 凶}$, Anna Song², Wankyu Eo ${ }^{3}$ \\ 1. Department of Clinical Oncology, College of Korean Medicine, Kyung Hee University; \\ 2. Department of Clinical Korean Medicine, Graduate School, Kyung Hee University; \\ 3. Department of Medical Oncology and Hematology, College of Medicine, Kyung Hee University. \\ $\triangle$ Corresponding author: Sookyung Lee, K.M.D., Ph.D. Associate Professor, Department of Clinical Oncology, College of Korean Medicine, Kyung Hee \\ University Hospital at Gangdong, 892 Dongnam-ro, Gangdong-gu, Seoul, 05278, Republic of Korea. Tel: +82-2-440-6229 Fax: +82-2-440-7267e-mail: \\ sookyung@khu.ac.kr.
}

(1) Ivyspring International Publisher. Reproduction is permitted for personal, noncommercial use, provided that the article is in whole, unmodified, and properly cited. See http://ivyspring.com/terms for terms and conditions.

Received: 2015.12.24; Accepted: 2016.03.16; Published: 2016.05.12

\begin{abstract}
Background: This study investigated the prognostic impact of serum ferritin for survival in patients with relapsed or refractory metastatic colorectal cancer (mCRC).

Methods: This retrospective cohort study reviewed clinicopathological characteristics and laboratory biomarkers in $120 \mathrm{mCRC}$ patients being treated with Korean Medicine (KM). The overall survival (OS) of patients was calculated using the Kaplan-Meier method, and statistical significance was assessed using the log-rank test. Univariate and multivariate analyses of Cox proportional hazards regression were used to evaluate the prognostic impact for survival in relapsed or refractory $\mathrm{mCRC}$ patients.

Results: Of the patients, $62.5 \%$ had liver metastases, $74.1 \%$ underwent greater than second-line chemotherapy, and $80.8 \%$ underwent surgery. Median OS was 7.6 months for all patients after the initiation of KM treatment, which was begun 13.7 months, on average, after mCRC diagnosis. Concerning prognostic factors such as the presence of liver metastasis $(p=0.024)$, high carcinoembryonic antigen level (CEA $>5 \mathrm{ng} / \mathrm{mL}, p=0.044$ ), elevated C-reactive protein (CRP $\geq$ $10.0 \mathrm{mg} / \mathrm{L}, p=0.000$ ), high absolute monocyte count (AMC $>413.3$ cells $/ \mu \mathrm{L}, p=0.034$ ), elevated serum ferritin (ferritin $\geq 150 \mathrm{ng} / \mathrm{mL}, p=0.002)$, low hemoglobin level $(\mathrm{Hb}<12 \mathrm{~g} / \mathrm{dL}, p=0.026)$ and low albumin (albumin $<3.5 \mathrm{~g} / \mathrm{dL}, p=0.003$ ) were associated with increased hazard ratios and poor survival. According to the multivariate proportional hazards model with backward and forward manners, albumin (albumin < $3.5 \mathrm{~g} / \mathrm{dL}$; hazard ratio (HR) 2.218, 95\% confidence interval $(\mathrm{Cl}) 1.135$ - 3.990, $p=0.019)$, CRP (CRP $\geq 10.0 \mathrm{mg} / \mathrm{L} ; \mathrm{HR} 2.506,95 \% \mathrm{Cl} 1.644-3.822, p=0.000)$, CEA (CEA $>5 \mathrm{ng} / \mathrm{mL} ; \mathrm{HR} 2.040,95 \% \mathrm{Cl} 1.203-3.460, p=0.008$ ), and serum ferritin (ferritin $\geq 150 \mathrm{ng} / \mathrm{mL} ; \mathrm{HR}$ $1.763,95 \% \mathrm{Cl} 1.169-2.660, p=0.007$ ) were independent prognostic biomarkers of survival in mCRC patients.
\end{abstract}

Conclusions: These results indicate that serum ferritin acts as an independent prognostic biomarker for survival in relapsed or refractory mCRC patients.

Key words: colorectal neoplasm, prognosis, survival, and ferritin.

\section{Introduction}

Colorectal cancer (CRC) is the third most common cancer in South Korea, and it is usually diagnosed at an advanced stage [1]. The precise prediction of survival in relapsed or refractory metastatic colorectal cancer (mCRC) patients is necessary to determine optimal treatment modalities in clinical practice. Over the past few decades, the identification of host-related factors in cancer outcomes has attracted considerable interest. In both preclinical and clinical research, host-related factors 
have been suggested, with convincing evidence, to be critical in the prediction of prognosis and the guidance of treatment [2].

Ferritin is a major iron binding protein that exists in both intracellular and extracellular compartments in most living organisms. Ferritin subfamilies including the unbound, iron free form of apoferritin, the iron-bound form of holoferritin, and simply ferritin, are composed of 24 subunits comprised of ferritin H-chains and ferritin L-chains with a hollow spherical cage [3]. Not only does serum ferritin act as a critical marker of iron storage and delivery [4], recent studies have also demonstrated that elevated serum ferritin levels are indicative of pathological processes in immunosuppression [5], angiogenesis [6], and proliferation [7]. This evidence suggests that elevated serum ferritin could be a potential biomarker of malignant disease. Since Hazard et al. first reported a relationship between ferritin and cancer in 1977 [8], elevated serum ferritin levels have been seen in breast cancer [9], pancreatic cancer [10], non-small cell lung cancer [11, 12], hepatocellular carcinoma [13], leukemia [14], and lymphoma [15, 16].

Regarding the relationship between serum ferritin concentration and the risk of colorectal cancer, several clinical studies have shown conflicting results [17-19]. One study reported that serum ferritin was inversely associated with colon cancer risk, whereas several studies showed no impact of preoperative serum ferritin on survival in early stage CRC [20, 21]. Furthermore, no relationship was seen between serum ferritin and the pathologic type, tumor site, size, and disease stage of CRC [22].

Until now, most studies addressing the clinical significance of serum ferritin have focused on its relationship with newly diagnosed cancer. Previous studies have been controversial in the role of serum ferritin in CRC. However, elevated serum ferritin levels are commonly observed in advanced cancer in clinical practice. To enhance the clinical application of serum ferritin, it is necessary to evaluate its relationship with survival in metastatic cancer patients. This study aims to assess the relationship between serum ferritin and survival time and to identify the potential ability to use serum ferritin level to predict survival in $\mathrm{mCRC}$.

\section{Methods}

This retrospective cohort study was performed by reviewing medical records. The institutional review board of Kyung Hee University Hospital at Gangdong approved this study (KHNMC-OH-IRB 2015-12003).

\section{Patients}

Cytologically confirmed mCRC patients over 20 years of age who underwent laboratory tests between June 2006 and April 2013 were included. All subjects experienced relapsed or refractory mCRC from standard chemotherapy or were unqualified for conventional treatment modalities due to poor performance status, age, or comorbidities.

\section{Measurements}

Patient clinicopathologic characteristics and laboratory measurements were investigated. Eastern Cooperative Oncology Group performance status (ECOG-PS), body mass index, tumor site, the presence of liver metastasis, and prior treatment modalities including surgery, chemotherapy, and radiotherapy were assessed as clinicopathologic characteristics. Laboratory measures including hemoglobin $(\mathrm{Hb})$, serum ferritin, platelets, albumin, C-reactive protein (CRP), carcinoembryonic antigen (CEA), and carbohydrate antigen 19-9 (CA19-9) levels were assessed. White blood cells (WBC), total WBC counts, absolute neutrophil count (ANC), absolute lymphocyte count (ALC), and absolute monocyte count (AMC) were included in univariate and multivariate analyses. The prognostic factor cut-off values were determined according to the reference values of each biomarker. The CRP cut-off value was set at $10.0 \mathrm{mg} / \mathrm{L}$, which was commonly used in systemic inflammation studies, and hemoglobin was set at $12.0 \mathrm{~g} / \mathrm{dL}$, which was at the low range of normal regardless of sex. In biomarkers without reference values, the cut-off values were obtained by ROC curves.

\section{Overall Survival (OS)}

OS was defined as the time from the first day of treatment to the time of death from any cause. When patients were lost to follow-up or if death was not recorded, the patient was censored. The survival time of censored patients was defined as the period from treatment initiation to the last day of follow-up or to the date on which survival was investigated.

\section{Treatment}

Korean medicine (KM), which manages patients with herbal medicines and acupuncture, was used as treatment. The main anticancer agent used was Rhus verniciflua Stokes (RVS) extract. RVS is also known as lacquer tree, which grows in East Asia. The various studies exploring RVS have reported anti-proliferative effects, reductions in apoptotic activity, anti-angiogenic effects, and anti-tumor migration effects [23-25]. RVS was extracted by standardized methods with water at $95^{\circ} \mathrm{C}$ under 1 
atmosphere of pressure and was then concentrated and lyophilized into powdered form. After depleting the toxic allergen urushiol, RVS extract was examined to ensure the absence of urushiol and to identify the amount of other compounds to ensure constant quality. For convenient administration, $500 \mathrm{mg}$ of RVS extract was contained in a capsule. Patients usually took $1500 \mathrm{mg}$ of RVS extract per day.

\section{Statistical Analysis}

The OS curve was calculated using the Kaplan-Meier method, and statistical significance was assessed using the log-rank test. The impact of prognostic factors for predicting survival was analyzed using Cox proportional hazards regression. Univariate analysis was performed with each potential prognostic factor. Multivariate proportional hazards regression was performed with statistically significant factors from the univariate analysis (factors with $p$-values less than 0.05 ). To ensure precise model prediction without complications caused by overlapping factors, high priority factors were entered for multivariate analysis, and low priority factors were removed. To assess the relationship between serum ferritin and other factors, Pearson's correlation coefficient tests were performed, and subgroup analyses using chi-square tests were conducted to identify other potential factors according to serum ferritin level. Receiver operating characteristic (ROC) curves were used to determine optimal cut-off values for biomarkers without reference values. The optimal cut-off values were determined by the maximum joint of sensitivity and specificity to indicate discrimination on survival. All statistical analyses were conducted using SPSS (Version 18.0; SPSS Inc., Chicago, IL, USA). $P$-values less than 0.05 were considered statistically significant.

\section{Results}

Patient clinicopathological characteristics and laboratory markers are summarized in Table 1 . Of the 120 patients, $59(49.2 \%)$ were male, and 38 patients $(31.7 \%)$ were over 65 years of age. Of the 120 patients, grade $0,1,2,3$, and 4 ECOG-PS scores were found in 1 $(0.8 \%), 70(58.3 \%), 37(30.8 \%), 9(7.5 \%)$, and $3(2.5 \%)$ patients, respectively. There were $88(73.3 \%)$ colon cancer cases and $32(26.7 \%)$ rectal cancer cases. The majority of patients $(80.8 \%)$ underwent surgical operation; meanwhile, radiotherapy was conducted in $33(27.5 \%)$ patients. Fifty-five patients $(45.8 \%)$ underwent greater than third-line chemotherapy, 34 patients $(28.3 \%)$ received second-line chemotherapy, and in total, 105 patients $(87.5 \%)$ had undergone at least one prior chemotherapy regimen. Liver metastases were seen in 75 patients $(62.5 \%)$. The median time to initiate $\mathrm{KM}$ treatment was 13.7 months after mCRC diagnosis (range, 0.1 - 79.6 months) (Table $1)$.

Table 1. Characteristics of enrolled $m C R C$ patients.

\begin{tabular}{|c|c|c|c|}
\hline Variables & Total & $\mathrm{N}$ & $(\%)$ \\
\hline \multicolumn{4}{|l|}{$\begin{array}{l}\text { Clinicopathological } \\
\text { factors }\end{array}$} \\
\hline Age (years) & $<65 / \geq 65$ & $82 / 38$ & $68.3 / 31.7$ \\
\hline Sex & Male / Female & 59 / 61 & 49.2 / 50.8 \\
\hline ECOG-PS & $0 / 1 / 2 / 3 / 4$ & $\begin{array}{l}1 / 70 / 37 / \\
9 / 3\end{array}$ & $\begin{array}{l}0.8 / 58.3 / 30.8 / \\
7.5 / 2.5\end{array}$ \\
\hline Tumor Site & Colon / Rectum & 88 / 32 & $73.3 / 26.7$ \\
\hline BMI $\left(\mathrm{kg} / \mathrm{m}^{2}\right)$ & $\begin{array}{l}<18.5 / 18.5-22.9 / \\
\geq 23\end{array}$ & $\begin{array}{l}16 / 54 / 48 \\
\text { a }\end{array}$ & $13.3 / 45.0 / 40.0$ \\
\hline Liver Metastasis & No / Yes & $45 / 75$ & $37.5 / 62.5$ \\
\hline Prior Surgery & No / Yes & $23 / 97$ & $19.2 / 80.8$ \\
\hline Prior Chemotherapy & $\begin{array}{l}\text { None } / 1^{\text {st }} \text { line } / 2^{\text {nd }} \\
\text { line } / \geq 3^{\text {rd }} \text { line }\end{array}$ & $\begin{array}{l}15 / 16 / 34 \\
/ 55\end{array}$ & $\begin{array}{l}12.5 / 13.3 / 28.3 \\
/ 45.8\end{array}$ \\
\hline $\begin{array}{l}\text { Prior Radiotherapy } \\
\text { Laboratory factors }\end{array}$ & No / Yes & $87 / 33$ & $72.5 / 27.5$ \\
\hline CEA (ng/mL) & $\leq 5 />5$ & $22 / 95 b$ & $18.3 / 79.2$ \\
\hline CA19-9 (U/mL) & $\leq 27 />27$ & $40 / 57 \mathrm{c}$ & 41.2 / 58.8 \\
\hline $\mathrm{Hb}(\mathrm{g} / \mathrm{dL})$ & $<12 / \geq 12$ & 59 / 61 & 49.2 / 50.8 \\
\hline Albumin (g/dL) & $<3.5 / \geq 3.5$ & 12 / 108 & $10.0 / 90.0$ \\
\hline CRP (mg/L) & $<10.0 / \geq 10.0$ & $75 / 45$ & $62.5 / 37.5$ \\
\hline $\operatorname{PLT}\left(\times 10^{3} / \mu \mathrm{L}\right)$ & $<400 / \geq 400$ & $110 / 10$ & $91.7 / 8.3$ \\
\hline Ferritin & $<150 / \geq 150$ & 79 / 41 & $65.8 / 34.2$ \\
\hline $\mathrm{WBC}\left(\times 10^{3} / \mu \mathrm{L}\right)$ & $<10.0 / \geq 10.0$ & 109 / 11 & $90.8 / 9.2$ \\
\hline ANC (cells $/ \mu \mathrm{L})$ & $\leq 4336.0 />4336.0$ & $60 / 60$ & $50.0 / 50.0$ \\
\hline ALC (cells/ $\mu \mathrm{L})$ & $\leq 1291.1 />1291.1$ & $60 / 60$ & $50.0 / 50.0$ \\
\hline AMC (cells $/ \mu \mathrm{L})$ & $\leq 413.3 />413.3$ & $47 / 73$ & 39.2 / 60.8 \\
\hline
\end{tabular}

The median OS of enrolled patients was 7.6 months (range, 0.8 - 82.2 months), and the median treatment duration was 3.1 months (range, 0.03 - 33.30 months). Compared to the survival curve based on biomarker reference values, the presence of liver metastasis, high CEA level, low albumin and $\mathrm{Hb}$ levels, increased AMC, and high levels of CRP and ferritin showed poor survival outcomes. The median OS of patients with low $\mathrm{Hb}(\mathrm{Hb}<12 \mathrm{~g} / \mathrm{dL})$ was 5.9 months, and the $\mathrm{OS}$ in patients with high $\mathrm{Hb}(\mathrm{Hb} \geq 12$ $\mathrm{g} / \mathrm{dL})$ was 10.1 months $(p=0.025)$. Furthermore, high $\mathrm{Hb}$ levels were associated with a significant reduction in mortality risk (HR, 0.654; 95\% CI, $0.450-0.950 ; p=$ $0.026)$. The median OS of patients with low albumin (albumin $<3.5 \mathrm{~g} / \mathrm{dL}$ ) was 2.0 months, and OS in high albumin patients (albumin $\geq 3.5 \mathrm{~g} / \mathrm{dL}$ ) was 8.7 months $(p=0.002)$. High albumin levels were associated with a significant increase in survival (HR, $0.402 ; 95 \%$ CI, $0.219-0.736 ; p=0.003)$. The median OS of patients with low CRP levels (CRP $<10.0 \mathrm{mg} / \mathrm{L})$ was 11.4 months, and OS in patients with high CRP levels (CRP $\geq 10.0 \mathrm{mg} / \mathrm{L})$ was 4.2 months $(p=0.000)$. 
High CRP levels were associated with poor survival outcomes (HR, 2.869; 95\% CI, $1.924-4.280 ; p=0.000)$. The median OS of patients with low CEA levels (CEA $\leq 5 \mathrm{ng} / \mathrm{mL}$ ) was 12.0 months, and OS in patients with high CEA levels (CEA $>5 \mathrm{ng} / \mathrm{mL}$ ) was 6.2 months $(p$ $=0.041)$. High CEA levels were associated with shortened survival (HR, 1.668; 95\% CI, 1.015 - 2.743; $p$ $=0.044)$. The median OS of patients with low ferritin (ferritin < $150 \mathrm{ng} / \mathrm{mL}$ ) was 10.1 months, and the median OS for high ferritin (ferritin $\geq 150 \mathrm{ng} / \mathrm{mL}$ ) was 4.3 months $(p=0.001)$. Patients with high serum ferritin levels showed a significantly poorer survival outcome (HR, 1.878; 95\% CI, 1.268 - 2.781; $p=0.002$ ). The median OS of patients with low AMC (AMC $\leq$ 413.25 cells $/ \mu \mathrm{L}$ ) was 10.0 months, and the median OS of those with high AMC (AMC $>143.25$ cells $/ \mu \mathrm{L}$ ) was 5.9 months $(p=0.032)$. Patients with increased AMC showed increased risk of mortality (HR, 1.517; 95\% CI, $1.033-2.229 ; p=0.034$ ).

Univariate analysis was performed to determine predictable factors for multivariable analysis of proportional hazards regression. Among the clinicopathological factors, the presence of liver metastasis significantly increased the hazard ratio for survival in mCRC patients. Regarding laboratory factors, increased AMC (AMC > 413.3 cells $/ \mu \mathrm{L}$ ), elevated CRP level (CRP $\geq 10.0 \mathrm{mg} / \mathrm{L})$, high CEA level (CEA > $5 \mathrm{ng} / \mathrm{mL}$ ), elevated serum ferritin (ferritin $\geq 150 \mathrm{ng} / \mathrm{mL}$ ), low Hb level $(\mathrm{Hb}<12 \mathrm{~g} / \mathrm{dL}$ ), and low albumin (albumin $<3.5 \mathrm{~g} / \mathrm{dL}$ ) were significantly associated with poor survival outcomes (Table 2). Multivariate analysis using the Cox proportional hazards model with selection process was performed with all the significant factors from the univariate analysis in order to identify independent predictors for overall survival. Significant independent prognostic factors for survival that were run in the multivariate analysis model included ferritin, albumin, CRP, and CEA. Among these factors, high CEA level (CEA > 5 $\mathrm{ng} / \mathrm{mL}$ ) was the only tumor-related factor to significantly increase the hazard ratio for survival (HR, 2.040; 95\% CI, 1.203 - 3.460; $p=0.008$ ). The other factors including ferritin, CRP, and albumin, were host-related factors that reflect the systemic status of the patient. Elevated serum ferritin level (ferritin $\geq 150$ $\mathrm{ng} / \mathrm{mL}$ ) was significantly associated with an increased hazard ratio of mortality (HR, 1.763; 95\% CI, 1.169 - 2.660; $p=0.007)$. Elevated CRP levels (CRP $\geq$ $10.0 \mathrm{mg} / \mathrm{L}$ ) were associated with a shortened survival time (HR, 2.506; 95\% CI, $1.644-3.822 ; p=0.000)$, and low albumin (albumin < $3.5 \mathrm{~g} / \mathrm{dL}$ ) significantly increased the hazard ratio for survival (HR, 2.128; 95\% CI, $1.135-3.990 ; p=0.019$ ) (Table 3).
Table 2. Univariate analysis of potential prognostic factors for survival.

\begin{tabular}{|c|c|c|c|}
\hline \multirow{2}{*}{$\begin{array}{l}\text { Variable } \\
\text { Clinicopathological } \\
\text { factors }\end{array}$} & & Hazard Ratio $(95 \%$ CI) & $p$-value \\
\hline & & & \\
\hline \multirow[t]{5}{*}{ ECOG-PS } & & & 0.136 \\
\hline & 0 vs 1 & $0.488(0.067-3.561)$ & 0.479 \\
\hline & 0 vs 2 & $0.623(0.084-4.602)$ & 0.643 \\
\hline & 0 vs 3 & $0.927(0.116-7.384)$ & 0.943 \\
\hline & 0 vs 4 & $1.551(0.161-14.956)$ & 0.704 \\
\hline \multirow[t]{3}{*}{ BMI $\left(\mathrm{kg} / \mathrm{m}^{2}\right)$} & & & 0.135 \\
\hline & $<18.5$ vs $18.5-22.9$ & $0.577(0.327-1.019)$ & 0.058 \\
\hline & $<18.5$ vs $\geq 23$ & $0.581(0.327-1.033)$ & 0.064 \\
\hline Tumor Site & Colon / Rectum & $0.808(0.529-1.236)$ & 0.326 \\
\hline Liver Metastasis & No / Yes & $1.567(1.060-2.317)$ & 0.024 \\
\hline Prior Surgery & No / Yes & $0.864(0.542-1.378)$ & 0.539 \\
\hline \multirow[t]{4}{*}{ Prior Chemotherapy } & & & 0.275 \\
\hline & None vs $1^{\text {st }}$ line & $0.501(0.238-1.051)$ & 0.068 \\
\hline & None vs $2^{\text {nd }}$ line & $0.617(0.330-1.153)$ & 0.130 \\
\hline & None vs $\geq 3^{\text {rd }}$ line & $0.729(0.410-1.297)$ & 0.282 \\
\hline Prior Radiotherapy & No / Yes & $0.767(0.504-1.166)$ & 0.214 \\
\hline \multicolumn{4}{|l|}{ Laboratory factors } \\
\hline $\mathrm{Hb}(\mathrm{g} / \mathrm{dL})$ & $<12 / \geq 12$ & $0.654(0.450-0.950)$ & 0.026 \\
\hline Albumin $(\mathrm{g} / \mathrm{dL})$ & $<3.5 / \geq 3.5$ & $0.402(0.219-0.736)$ & 0.003 \\
\hline $\mathrm{CRP}(\mathrm{mg} / \mathrm{L})$ & $<10.0 / \geq 10.0$ & $2.869(1.924-4.280)$ & 0.000 \\
\hline $\operatorname{PLT}\left(\times 10^{3} / \mu \mathrm{L}\right)$ & $<400 / \geq 400$ & $1.760(0.909-3.406)$ & 0.093 \\
\hline Ferritin $(\mathrm{ng} / \mathrm{mL})$ & $<150 / \geq 150$ & $1.878(1.268-2.781)$ & 0.002 \\
\hline CEA (ng/mL) & $\leq 5 />5$ & $1.668(1.015-2.743)$ & 0.044 \\
\hline CA19-9 (U/mL) & $\leq 27 />27$ & $1.305(0.858-1.984)$ & 0.213 \\
\hline $\mathrm{WBC}\left(\times 10^{3} / \mu \mathrm{L}\right)$ & $<10.0 / \geq 10.0$ & $1.627(0.872-3.035)$ & 0.126 \\
\hline ANC (cells/ $\mu \mathrm{L})$ & $\leq 4336.0 />4336.0$ & $1.444(0.995-2.096)$ & 0.053 \\
\hline ALC (cells $/ \mu \mathrm{L})$ & $\leq 1291.1 />1291.1$ & $0.827(0.570-1.198)$ & 0.315 \\
\hline $\mathrm{AMC}($ cells $/ \mu \mathrm{L})$ & $\leq 413.3 />413.3$ & $1.517(1.033-2.229)$ & 0.034 \\
\hline
\end{tabular}

According to Pearson correlation coefficient tests between serum ferritin and the other potential prognostic factors, few factors were correlated with serum ferritin. The ECOG-PS $(r=0.291, p=0.001)$, total white blood cell counts $(r=0.197, p=0.031)$, absolute monocyte counts $(r=0.290, p=0.001)$, and CRP levels $(r=0.349, p=0.000)$ were positively correlated with serum ferritin level. In the subgroup analysis according to ferritin level, patients with high levels of serum ferritin (ferritin $\geq 150 \mathrm{ng} / \mathrm{mL}$ ) showed poor ECOG-PS $(p=0.025)$, increased CRP levels $(p=$ $0.000)$, and leukocytosis $(p=0.031)$ (Table 4$)$.

Table 3. Multivariate proportional hazards regression model.

\begin{tabular}{llll}
\hline Variable & & Hazard Ratio $(95 \% \mathrm{CI})$ & $p$-value \\
\hline Albumin $(\mathrm{g} / \mathrm{dL})$ & $\geq 3.5 /<3.5$ & $2.128(1.135-3.990)$ & 0.019 \\
CRP $(\mathrm{mg} / \mathrm{L})$ & $<10.0 / \geq 10.0$ & $2.506(1.644-3.822)$ & 0.000 \\
Ferritin $(\mathrm{ng} / \mathrm{mL})$ & $<150 / \geq 150$ & $1.763(1.169-2.660)$ & 0.007 \\
CEA $(\mathrm{ng} / \mathrm{mL})$ & $\leq 5 />5$ & $2.040(1.203-3.460)$ & 0.008 \\
\hline
\end{tabular}

$\mathrm{CRP}=\mathrm{C}$-reactive protein; $\mathrm{CEA}=$ carcinoembryonic antigen. 


\section{Discussion}

Colorectal cancer is the second leading cause of cancer death in the United States. Approximately 50 $60 \%$ of patients are diagnosed after developing colorectal metastases [26, 27], and $80-90 \%$ of these patients have unresectable metastatic liver disease at diagnosis [28]. Therefore, advanced CRC management is an important issue in clinical practice. FOLFOX (folinic acid, flurouracil, and oxaliplatin) is recommended as the first-line treatment regimen, and FOLFIRI (folinic acid, fluorouracil, and irinotecan hydrochloride) is the recommended second-line regimen. The median OS of FOLFOX as a first-line chemotherapy is approximately 20 months [29]. If disease progression is seen after treatment with second-line agents, targeted agents or supportive care are recommended.

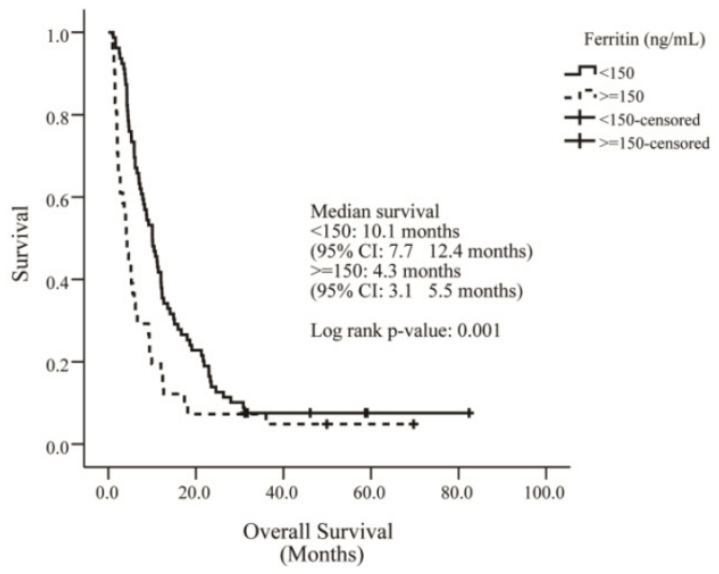

(A)

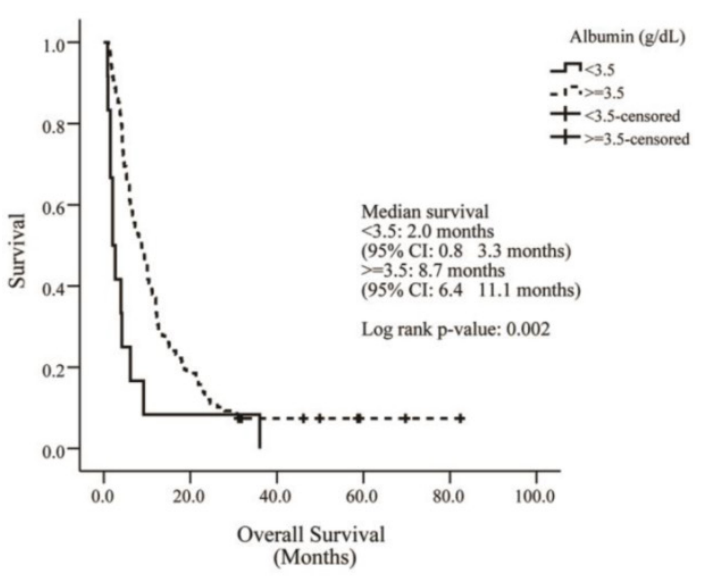

(C)
Table 4. Correlations between serum ferritin and patient characteristics.

\begin{tabular}{|c|c|c|c|}
\hline Variable & & $\begin{array}{l}\text { Correlation } \\
\text { coefficients }\end{array}$ & $p$-value \\
\hline \multicolumn{4}{|l|}{$\begin{array}{l}\text { Clinicopathological } \\
\text { factors }\end{array}$} \\
\hline ECOG-PS & $0 / 1 / 2 / 3 / 4$ & 0.291 & 0.001 \\
\hline BMI $\left(\mathrm{kg} / \mathrm{m}^{2}\right)$ & $<18.5 / 18.5-22.9 / \geq 23$ & -0.022 & 0.812 \\
\hline Liver Metastasis & No / Yes & 0.122 & 0.183 \\
\hline Prior Surgery & No / Yes & 0.083 & 0.368 \\
\hline Prior Chemotherapy & $\begin{array}{l}\text { None / } 1^{\text {st }} \text { line } / 2^{\text {nd }} \text { line / } \geq 3^{\text {rd }} \\
\text { line }\end{array}$ & 0.167 & 0.068 \\
\hline Prior Radiotherapy & No / Yes & 0.029 & 0.757 \\
\hline \multicolumn{4}{|l|}{ Laboratory factors } \\
\hline $\mathrm{CEA}(\mathrm{ng} / \mathrm{mL})$ & $\leq 5 />5$ & 0.033 & 0.728 \\
\hline CA19-9 (U/mL) & $\leq 27 />27$ & -0.028 & 0.782 \\
\hline $\mathrm{Hb}(\mathrm{g} / \mathrm{dL})$ & $<12 / \geq 12$ & 0.006 & 0.952 \\
\hline Albumin (g/dL) & $<3.5 / \geq 3.5$ & -0.170 & 0.064 \\
\hline $\mathrm{CRP}(\mathrm{mg} / \mathrm{L})$ & $<10.0 / \geq 10.0$ & 0.349 & 0.000 \\
\hline $\operatorname{PLT}\left(\times 10^{3} / \mu \mathrm{L}\right)$ & $<400 / \geq 400$ & 0.037 & 0.688 \\
\hline $\mathrm{WBC}\left(\times 10^{3} / \mu \mathrm{L}\right)$ & $<10.0 / \geq 10.0$ & 0.197 & 0.031 \\
\hline ANC (cells $/ \mu \mathrm{L})$ & $\leq 4336.0 />4336.0$ & 0.158 & 0.085 \\
\hline ALC (cells $/ \mu \mathrm{L})$ & $\leq 1291.1 />1291.1$ & -0.158 & 0.085 \\
\hline AMC (cells $/ \mu \mathrm{L})$ & $\leq 413.3 />413.3$ & 0.290 & 0.001 \\
\hline
\end{tabular}

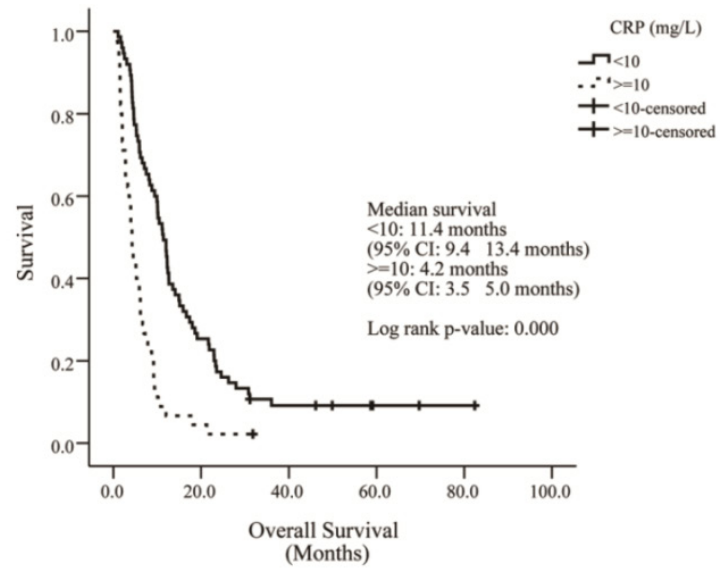

(B)

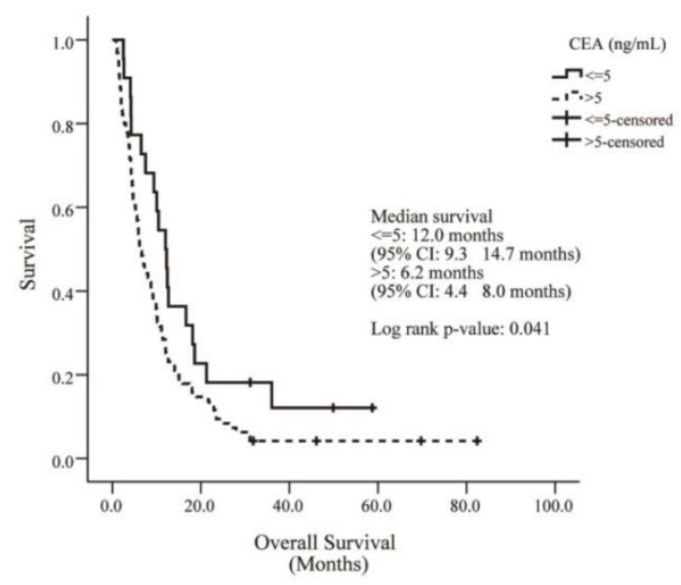

(D)

Figure 1. Overall survival of patients according to ferritin $(A), C R P(B)$, albumin $(C)$ and CEA levels $(D)$. CRP = C-reactive protein; $C E A=$ carcinoembryonic antigen. 
Table 5. Subgroup characteristics according to serum ferritin.

\begin{tabular}{|c|c|c|c|c|}
\hline \multirow[t]{2}{*}{ Variable } & & \multirow{2}{*}{$\frac{\text { Ferritin }<150(\mathrm{ng} / \mathrm{mL})}{79}$} & \multirow{2}{*}{$\begin{array}{l}\text { Ferritin } \geq 150(\mathrm{ng} / \mathrm{mL}) \\
41\end{array}$} & \multirow[t]{2}{*}{$p$-value } \\
\hline & & & & \\
\hline \multicolumn{5}{|c|}{ Clinicopathological factors } \\
\hline ECOG-PS & $0 / 1 / 2 / 3 / 4$ & $1 / 54 / 19 / 4 / 1$ & $0 / 16 / 18 / 5 / 2$ & 0.025 \\
\hline $\mathrm{BMI}\left(\mathrm{kg} / \mathrm{m}^{2}\right)$ & $<18.5 / 18.5-22.9 / \geq 23$ & $11 / 34 / 33$ a & $5 / 20 / 15 b$ & 0.803 \\
\hline Liver Metastasis & No / Yes & $33 / 46$ & $12 / 29$ & 0.180 \\
\hline Prior Surgery & No / Yes & 17 / 62 & $6 / 35$ & 0.363 \\
\hline Prior Chemotherapy & None $/ 1^{\text {st }}$ line $/ 2^{\text {nd }}$ line $/ \geq 3^{\text {rd }}$ line & $14 / 10$ / 21 / 34 & $1 / 6 / 13 / 21$ & 0.124 \\
\hline Prior Radiotherapy & No / Yes & 58 / 21 & $29 / 12$ & 0.755 \\
\hline \multicolumn{5}{|l|}{ Laboratory factors } \\
\hline CEA (ng/mL) & $\leq 5 />5$ & $15 / 61^{c}$ & $7 / 34$ & 0.725 \\
\hline CA19-9 (U/mL) & $\leq 27 />27$ & $27 / 40 \mathrm{~d}$ & $13 / 17$ e & 0.779 \\
\hline $\mathrm{Hb}(\mathrm{g} / \mathrm{dL})$ & $<12 / \geq 12$ & $39 / 40$ & $20 / 21$ & 0.951 \\
\hline Albumin (g/dL) & $<3.5 / \geq 3.5$ & $5 / 74$ & $7 / 34$ & 0.063 \\
\hline CRP (mg/L) & $<10.0 / \geq 10.0$ & $59 / 20$ & $16 / 25$ & 0.000 \\
\hline $\operatorname{PLT}\left(\times 10^{3} / \mu \mathrm{L}\right)$ & $<400 / \geq 400$ & $73 / 6$ & $37 / 4$ & 0.685 \\
\hline $\mathrm{WBC}\left(\times 10^{3} / \mu \mathrm{L}\right)$ & $<10.0 / \geq 10.0$ & $75 / 4$ & $34 / 7$ & 0.031 \\
\hline ANC (cells $/ \mu \mathrm{L})$ & $\leq 4336.0 />4336.0$ & 44 / 35 & $16 / 25$ & 0.083 \\
\hline ALC (cells $/ \mu \mathrm{L})$ & $\leq 1291.1 />1291.1$ & 35 / 44 & $25 / 16$ & 0.083 \\
\hline AMC (cells $/ \mu \mathrm{L})$ & $\leq 413.3 />413.3$ & 39 / 40 & $8 / 33$ & 0.001 \\
\hline
\end{tabular}

This study was performed with pathologically confirmed mCRC patients who experienced relapsed or refractory disease. At the initiation of $\mathrm{KM}$ management, the majority of patients (74.1\%) had undergone more than second-line chemotherapy, which means that this cohort consisted of advanced patients experiencing relapsed or refractory disease. In relapsed or refractory disease, it is important to precisely predict prognosis and to select optimal treatment modalities such as continuation of systemic chemotherapy, palliative care, supportive care, or alternative methods. KM has been widely used for advanced cancer patients who do not qualify for conventional standard therapy in Korea. Herbal medicine and acupuncture are the major treatment modalities of $\mathrm{KM}$, and in this study, the main anticancer agent used was the extract of Rhus verniciflua Stokes (RVS), which has been used to reduce abdominal masses since the $15^{\text {th }}$ century in Korea. According to reports, RVS has various anticancer effects such as anti-proliferative and apoptotic activity in several cancers and inhibition of migration mediated by matrix metalloproteinases [30-34].

For these advanced cancer patients, predicting prognosis is important for optimal treatment decisions. Thus, it is critical to identify available biomarkers to reflect survival time. Recently, a tremendous number of studies have been conducted using biomarkers to predict response to treatment and to monitor disease progression. In addition, biomarkers can be used to select for patients who may respond to each therapy in different stages of clinical practice. Most of the studies using biomarkers to predict prognosis for CRC have been performed with early-stage patients or at the initiation of treatment, immediately after diagnosis. Previously, the anatomical extent of the tumor and the response to initial therapy have been the most commonly used prognostic factors. Predicting prognosis, especially in the relapsed or refractory phase of metastatic cancers, should be approached differently from early-stage cancers.

In biomarkers of colorectal cancer, CRP, leukocyte ratio, and oncogene mutations such Kirsten rat sarcoma viral oncogene homolog (KRAS) and epidermal growth factor receptor (EGFR) have been studied in clinical practice. Their prognostic impact has been assessed with early treatment responses such as chemosensitivity or tumor shrinkage. Recently, the development of detection techniques and a consensus on liquid biopsy have enabled circulating tumor cells and circulating free nucleic acid to be used as prognostic or predictive biomarkers after cancer diagnosis.

Originally, ferritin was known for its role in iron storage, and was used to indicate the total amount of iron in the body. Additionally, elevated ferritin levels are often indicative of anemia of chronic disease. Though the pathophysiological function of ferritin remains unclear, elevated levels of serum ferritin are correlated with pathological processes of inflammation, infection, and liver disease, implying ferritin's potential as a prognostic factor and clinical indicator [30]. Serum ferritin is predominantly composed of L-chains under normal physiological conditions, whereas heavy ferritin and the ratio of $\mathrm{H}$ to $\mathrm{L}$ ferritins are increased in many malignant 
conditions [31]. Although the mechanism remains unclear, studies have revealed that $\mathrm{H}$-ferritin plays a role in malignancy, and it could be a potential biomarker to detect cancer $[8,30,32]$.

Regarding colorectal cancer, several clinical studies show conflicting results on the relationship between serum ferritin level and the risk of colorectal cancer [17-19]. Serum ferritin has been reported to have an inverse association with the risk of colon cancer, whereas a few studies showed that preoperative serum ferritin levels had no impact on predicted survival in early-stage CRC [20, 21]. In addition, serum ferritin levels upon cancer diagnosis were not associated with the CRC pathologic type, tumor site, tumor size, or disease stage [22]. The prognostic impact on survival of categorized preoperative serum ferritin was assessed, but the results were not statistically significant without hazard ratios [33].

In this study, the prognostic impact of serum ferritin was assessed with other well-known prognostic factors using Cox proportional hazards regression in $\mathrm{mCRC}$ patients. On multivariate analysis using Cox proportional hazards modeling in a stepwise manner, albumin, ferritin, CRP, and CEA consistently remained in the final models to predict survival. As an independent prognostic factor for survival, serum ferritin was significant enough a predictor to compete with other well-known factors such as albumin, CRP, and CEA. Albumin is a common indicator of survival, and it also provides nutritional status information. Additionally, CRP is a marker that increases in response to inflammation. Both albumin and CRP are the main factors in the Glasgow Prognostic Score (GPS), which is used to reflect the status of systemic inflammation. The GPS is widely used to predict prognosis in clinical practice. These results show that serum ferritin is a strong prognostic factor for survival, comparable to CRP and albumin.

Compared to previous studies, the prognostic significance of serum ferritin could be reflected on the characteristics of patient groups, relapsed or refractory metastatic cancer patients. In the mCRC patients of this study, $74 \%$ underwent greater than second-line chemotherapy, $41 \%$ showed more than ECOG 2, and $62.5 \%$ had liver metastases. The characteristics of relapsed or refractory metastatic cancer were related to the significant impacts of serum ferritin level on survival time. Based on these results, high serum ferritin level may indicate poor prognosis for survival in metastatic stage of cancer patients.

To identify other prognostic factors that may impact serum ferritin level, correlation analyses were performed between serum ferritin level, patient clinicopathological characteristics, and laboratory markers. Of these factors, ECOG-PS $(r=0.291, p=$ $0.001)$, total WBCs $(r=0.197, p=0.031)$, AMC $(r=$ $0.290, p=0.001)$, and CRP $(r=0.349, p=0.000)$ were significantly positively correlated with serum ferritin level. However, all of these correlations were weak, with correlation coefficients less than 0.4.

Two subgroup analyses according to the reference serum ferritin values, ferritin $<150 \mathrm{ng} / \mathrm{mL}$ and ferritin $\geq 150 \mathrm{ng} / \mathrm{mL}$, were performed to identify differences in other factor distributions (Table 5). The two groups were different in EOCG-PS grade $(p=$ $0.025)$, total WBCs $(p=0.031)$, and CRP level $(p=$ 0.000). Among these factors, ECOG-PS and WBCs did not show any influence on hazard ratios, whereas CRP strongly impacted the hazard ratio for survival in $\mathrm{mCRC}$ patients.

Although elevated CRP level was reported to increase the hazard ratio for mortality in CRC [34,35], in other studies to evaluate ferritin and CRP concurrently as prognostic factors, no efficacy of serum ferritin or CRP was showed in melanoma [36], ferritin was revealed strong prognostic value than CRP in breast cancer [37], elevation of both markers resulted significant decrease of OS in inoperable pancreatic cancer patients [38].

In this study, we identified serum ferritin to be a significant prognostic factor in determining survival, as well as in confirming the prognostic efficacy of CRP. In mCRC patients, serum ferritin and CRP can be used concurrently to predict prognosis. This finding implies that the relationship between ferritin and CRP is relevant to the pathophysiology of cancer, such as inflammation, malnutrition, and cachexia, as manifestation of advanced stage. Of the laboratory tests in clinical medicine, serum ferritin is more expensive to test compared with CRP. However, in clinical implication, ferritin can give various host-related information such as inflammation, response to oxidative stress, regulation of immune system as well as disorder of iron balance, whereas CRP is limited to imply only the systemic inflammation. Serum ferritin will emerge as an important biomarker in cancer, as its novel function with various mechanisms related carcinogenesis is recognized.

This study demonstrates that serum ferritin is a significant prognostic factor for survival in mCRC. In order to interpret the mechanism underlying these findings, biological studies with various approaches will be necessary, and well-designed prospective studies will also support these findings. 


\section{Conflicts of interest}

\section{We have no conflicts of interest to declare.}

\section{References}

1. Jung KW, Won YJ, Kong HJ, Oh CM, Lee DH, Lee JS. Cancer statistics in Korea: incidence, mortality, survival, and prevalence in 2011. Cancer Res Treat. 2014; 46: 109-23.

2. Goodwin PJ, Meyerhardt JA, Hursting SD. Host factors and cancer outcome. J Clin Oncol. 2010; 28: 4019-21.

3. Wang W, Knovich MA, Coffman LG, Torti FM, Torti SV. Serum ferritin: Past, present and future. Biochim Biophys Acta. 2010; 1800: 760-9.

4. Fisher J, Devraj K, Ingram J, Slagle-Webb B, Madhankumar AB, Liu X, et al. Ferritin: a novel mechanism for delivery of iron to the brain and other organs. Am J Physiol Cell Physiol. 2007; 293: C641-9.

5. Fargion S, Fracanzani AL, Brando B, Arosio P, Levi S, Fiorelli G. Specific binding sites for $\mathrm{H}$-ferritin on human lymphocytes: modulation during cellular proliferation and potential implication in cell growth control. Blood. 1991; 78: 1056-61.

6. Coffman LG, Parsonage D, D'Agostino R, Jr., Torti FM, Torti SV. Regulatory effects of ferritin on angiogenesis. Proc Natl Acad Sci U S A. 2009; 106: 570-5.

7. Alkhateeb AA, Han B, Connor JR. Ferritin stimulates breast cancer cells through an iron-independent mechanism and is localized within tumor-associated macrophages. Breast Cancer Res Treat. 2013; 137: 733-44.

8. Hazard JT, Drysdale JW. Ferritinaemia in cancer. Nature. 1977; 265: 755-6.

9. Jezequel P, Campion L, Spyratos F, Loussouarn D, Campone M, Guerin-Charbonnel C, et al. Validation of tumor-associated macrophage ferritin light chain as a prognostic biomarker in node-negative breast cancer tumors: A multicentric 2004 national PHRC study. Int J Cancer. 2012; 131: 426-37.

10. Kalousova M, Krechler T, Jachymova M, Kubena AA, Zak A, Zima T. Ferritin as an independent mortality predictor in patients with pancreas cancer. Results of a pilot study. Tumour Biol. 2012; 33: 1695-700.

11. Shi HB, Li XD, Jiang JT, Zhao WQ, Ji M, Wu CP. Serum ferritin is elevated in advanced non-small cell lung cancer patients and is associated with efficacy of platinum-based chemotherapy. J Cancer Res Ther. 2014; 10: 681-5.

12. Kukulj S, Jaganjac M, Boranic M, Krizanac S, Santic Z, Poljak-Blazi M. Altered iron metabolism, inflammation, transferrin receptors, and ferritin expression in non-small-cell lung cancer. Med Oncol. 2010; 27: 268-77.

13. Facciorusso A, Del Prete V, Antonino M, Neve V, Crucinio N, Di Leo A, et al. Serum ferritin as a new prognostic factor in hepatocellular carcinoma patients treated with radiofrequency ablation. J Gastroenterol Hepatol. 2014; 29: 1905-10.

14. Zhang XZ, Su AL, Hu MQ, Zhang XQ, Xu YL. Elevated serum ferritin levels in patients with hematologic malignancies. Asian Pac J Cancer Prev. 2014; 15: 6099-101.

15. Yoh KA, Lee HS, Park LC, Lee EM, Shin SH, Park DJ, et al. The prognostic significance of elevated levels of serum ferritin before chemotherapy in patients with non-Hodgkin lymphoma. Clin Lymphoma Myeloma Leuk. 2014; 14: 43-9.

16. Yamazaki E, Tomita N, Koyama S, Ogusa E, Ishii Y, Takahashi H, et al. Serum ferritin level is prognostic of patient outcome in extranodal NK/T cell lymphoma, nasal type. Med Oncol. 2014; 31: 149.

17. Tseng M, Greenberg ER, Sandler RS, Baron JA, Haile RW, Blumberg BS, et al. Serum ferritin concentration and recurrence of colorectal adenoma. Cancer Epidemiol Biomarkers Prev. 2000; 9: 625-30.

18. Chan AT, Ma J, Tranah GJ, Giovannucci EL, Rifai N, Hunter DJ, et al. Hemochromatosis gene mutations, body iron stores, dietary iron, and risk of colorectal adenoma in women. J Natl Cancer Inst. 2005; 97: 917-26.

19. Cross AJ, Gunter MJ, Wood RJ, Pietinen P, Taylor PR, Virtamo J, et al. Iron and colorectal cancer risk in the alpha-tocopherol, beta-carotene cancer prevention study. Int J Cancer. 2006; 118: 3147-52.

20. Giessen C, Nagel D, Glas M, Spelsberg F, Lau-Werner U, Modest DP, et al. Evaluation of preoperative serum markers for individual patient prognosis in stage I-III rectal cancer. Tumour Biol. 2014; 35: 10237-48.

21. Giessen-Jung C, Nagel D, Glas M, Spelsberg F, Lau-Werner U, Modest DP, et al. Preoperative serum markers for individual patient prognosis in stage I-III colon cancer. Tumour Biol. 2015; 36: 7897-906.

22. Li F, Kishida T, Kobayashi M. Serum iron and ferritin levels in patients with colorectal cancer in relation to the size, site, and disease stage of cancer. J Gastroenterol. 1999; 34: 195-9.

23. Choi WC, Lee JH, Lee EO, Yoon SW, Ahn KS, Kim SH. Study on antiangiogenic and antitumor activities of processed Rhus verniciflua Stokes extract. Korea J Oriental Physiology \& Pathology. 2006; 20: 825-9.

24. Kim JH, Kim HP, Jung CH, Hong MH, Hong MC, Lee SD, et al. Inhibition of cell cyle progression via p27Kip1 upregulation and apoptosis induction by an ethanol extract of Rhus vernificlua Stokes in AGS gastric cancer cells. Int J Mol Med. 2006; 18: 201-8.

25. Park JH, Moon G. Effect of allergen removed Rhus verniciflua extract on inhibition of tumor metastasis. J of Kor Traditional Oncology. 2010; 15: 47-61.

26. Yoo PS, Lopez-Soler RI, Longo WE, Cha CH. Liver resection for metastatic colorectal cancer in the age of neoadjuvant chemotherapy and bevacizumab. Clin Colorectal Cancer. 2006; 6: 202-7.
27. Van Cutsem E, Nordlinger B, Adam R, Kohne CH, Pozzo C, Poston G, et al. Towards a pan-European consensus on the treatment of patients with colorectal liver metastases. Eur J Cancer. 2006; 42: 2212-21.

28. Dawood O, Mahadevan A, Goodman KA. Stereotactic body radiation therapy for liver metastases. Eur J Cancer. 2009; 45: 2947-59.

29. Chibaudel B, Maindrault-Goebel F, Lledo G, Mineur L, Andre T, Bennamoun $\mathrm{M}$, et al. Can chemotherapy be discontinued in unresectable metastatic colorectal cancer? The GERCOR OPTIMOX2 Study. J Clin Oncol. 2009; 27: 5727-33.

30. Cazzola M, Arosio P, Bellotti V, Bergamaschi G, Dezza L, Iacobello C, et al. Immunological reactivity of serum ferritin in patients with malignancy. Tumori. 1985; 71: 547-54

31. Fan K, Gao L, Yan X. Human ferritin for tumor detection and therapy. Wiley Interdiscip Rev Nanomed Nanobiotechnol. 2013; 5: 287-98.

32. Torti FM, Torti SV. Regulation of ferritin genes and protein. Blood. 2002; 99: 3505-16.

33. Lorenzi M, Lorenzi B, Vernillo R. Serum ferritin in colorectal cancer patients and its prognostic evaluation. Int J Biol Markers. 2006; 21: 235-41.

34. Goyal A, Terry MB, Jin Z, Siegel AB. C-reactive protein and colorectal cancer mortality in U.S. adults. Cancer Epidemiol Biomarkers Prev. 2014; 23: 1609-18.

35. Shibutani M, Maeda $K$, Nagahara $H$, Noda E, Ohtani H, Nishiguchi Y, et al. Prognostic significance of the preoperative serum C-reactive protein level in patients with stage IV colorectal cancer. Surg Today. 2015; 45: 315-21.

36. Bouwhuis MG, Collette $\mathrm{S}$, Suciu S, de Groot ER, Kruit WH, Ten Hagen TL, et al. Changes of ferritin and CRP levels in melanoma patients treated with adjuvant interferon-alpha (EORTC 18952) and prognostic value on treatment outcome. Melanoma Res. 2011; 21: 344-51.

37. Alkhateeb AA, Leitzel K, Ali SM, Campbell-Baird C, Evans M, Fuchs EM, et al. Elevation in inflammatory serum biomarkers predicts response to trastuzumab-containing therapy. PLoS One. 2012; 7: e51379.

38. Alkhateeb A, Zubritsky L, Kinsman B, Leitzel K, Campbell-Baird C, Ali SM, et al. Elevation in multiple serum inflammatory biomarkers predicts survival of pancreatic cancer patients with inoperable disease. J Gastrointest Cancer. 2014; 45. $161-7$ 